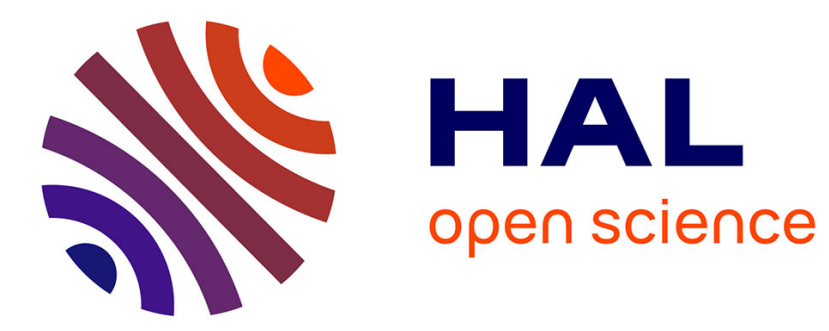

\title{
PREPARATION AND PROPERTIES OF POLYSILANES : MODEL COMPOUNDS FOR HYDROGENATED a-Si
}

P. John, I. Odeh, M. Thomas, J. Wilson

\section{- To cite this version:}

P. John, I. Odeh, M. Thomas, J. Wilson. PREPARATION AND PROPERTIES OF POLYSILANES : MODEL COMPOUNDS FOR HYDROGENATED a-Si. Journal de Physique Colloques, 1981, 42 (C4), pp.C4-651-C4-654. 10.1051/jphyscol:19814143 . jpa-00220764

HAL Id: jpa-00220764

https://hal.science/jpa-00220764

Submitted on 1 Jan 1981

HAL is a multi-disciplinary open access archive for the deposit and dissemination of scientific research documents, whether they are published or not. The documents may come from teaching and research institutions in France or abroad, or from public or private research centers.
L'archive ouverte pluridisciplinaire HAL, est destinée au dépôt et à la diffusion de documents scientifiques de niveau recherche, publiés ou non, émanant des établissements d'enseignement et de recherche français ou étrangers, des laboratoires publics ou privés. 
JOURNAL DE PHYSIQUE

Colioque C4, supplément au $n^{\circ} 10$, 'lome 4\%, octobre 1981

page $44-651$

PREPARATION AND PROPERTIES OF POLYSILANES : MODEL COMPOUNDS FOR HYDROGENATED a-Si

\author{
P. John, I.M. Odeh, M.J.K. Thomas and J.I.B. Wilson* \\ Department of Chemistry, \\ * Department of Physics, \\ lleriot-Watt University, Riccurton, Currie, Lidinburgh EH74 4AS, U.K.
}

\begin{abstract}
The infrared and electronic spectra of hydrogenated polysilanes, of approximate composition $-\left(\mathrm{SiH}_{2}\right)_{-}$and $-(\mathrm{SiH})-$ have been compared to hydrogenated a-Si. An investigation of the oxidative stability of films of these materials by infrared spectroscopy has been used to interpret 'ageing' phenomena exhibited by certain glow-discharge a-Si films prepared at high r.f. powers $(>100 W)$.
\end{abstract}

1. Introduction An understanding of the role of polysilane chains, notably $-\left(\mathrm{SiH}_{2}\right)_{\bar{n}}$, is important in elucidating the structure of certain hydrogenated amorpholis silicon films. The presence of $-\left(\mathrm{SiH}_{2}\right)-$ has been inferred [l] from the $840 \mathrm{~cm}^{-1}$ band which may be assigned to the $b$ wagging vibration $\neq$ of the entire chain when $n \geqslant 2$. Such catenates have been lumplicated [2] as an integral part of the hydrogen-rich phase in a-Si films exhibiting 'columnar' morphology [3] and may be responsible for their poor oxidative stability. Isothermal dehydrogenation studies $[4]$ of $\mathbf{r} . \hat{f}$. $2-S i$ films demonstrate that $-\left(S i H_{2}\right)-\bar{n}$ chains are degraded rapidiy at ca. $350^{\circ} \mathrm{C}$ and this process has been tertatively ${ }^{n}$ associated with striated fractures [5] peculiar to r.f. films prepared at low substrate temperature.

Notwithstanding the importance of such material as model compounds for structural entities in a-Si, linear chain polysilanes, $-\left(\mathrm{SiH}_{2}\right) \overline{\text {, }}$, are potential precursors to one dimensional semiconductors and offer the prospect for an alternative, chemically based, route to a-Si.

2. Preparation Dichlorosilane, $\mathrm{SiH}_{2} \mathrm{Cl}_{2}$, was reacted in vacuo with granular Li suspended in rigorously dried tetrahydrofuran at room temperature. The initial mole ratio of $\mathrm{Li}$ : $\mathrm{SiH}_{2} \mathrm{Cl}_{2}$ was 20 : 1 for the present results. An airsensitive orange/yellow solid was deposited of approximate composition $-\left(\mathrm{SiH}_{2}\right)$ (vide infre). Similarly a brown material, $-\left(S_{i H}\right)_{\vec{n}}$, was synthesised from the $\mathrm{Li}$ reduction of trichlorosilane, $\mathrm{SiHCl}_{3}$, in tetrahydrofuran.

3. Characterisation

3.1. Infrared Spectroscony The ir transmission spectra of $-\left(\mathrm{SiH}_{2}\right)-$ and $-(\mathrm{SiH})-$, dispersed in a nujol mul1, are shown in figure 1. Two features of the spectra" are of import to the interpretation of the ir spectroscopy of hydrogenated a-si. First, the unresolved symmetric $\left(b_{3 u}\right)$ and asymmetric (b $)$ silicon-hydrogen stretching modes of $-\left(\mathrm{SiH}_{2}\right)_{\mathrm{n}}$ occur $3 \mathrm{u}_{\text {with }}$ a band maxima $2 \mathrm{u}_{\text {at }} 2100 \mathrm{~cm}$. In

$\ddagger$ we adopt a $D_{2 h}$ line group symmetry for $-\left(S_{i} H_{2}\right)-$ 
contrast $-(\mathrm{SiH})-$ exhibits a stretching mode at $2000 \mathrm{~cm}^{-1}$. Secondly, a characteristic doublet occurs for $-\left(\mathrm{SiH}_{2}\right)_{-}$in the bending region at $905 \mathrm{~cm}^{-1}$ and $850 \mathrm{~cm}^{-1}$; these bands are assigned to Ehe bending ( $b_{2 u}$ ) mode of $\mathrm{SiH}_{2}$ groups and the wagging $\left(b_{2 u}\right)$ mode of an extended polysilane $-\left(S_{i} H_{2}\right)_{n}$ chain.

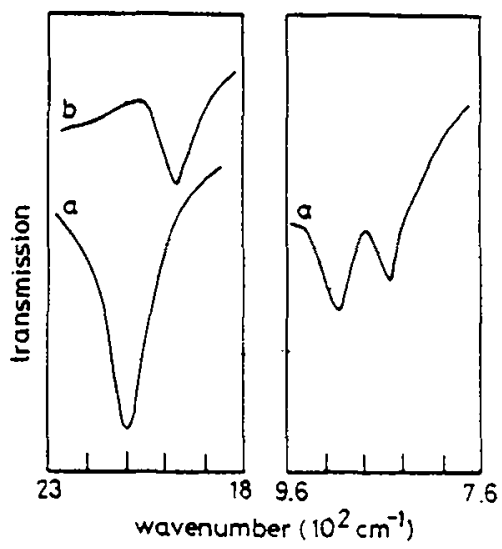

Fig. 1

Infrared transmission spectra of $-\left(\mathrm{SiH}_{2}\right) \bar{n}(\mathrm{a})$ and $-(\mathrm{SiH})-(b)$

3.2. Electronic Spectroscopy Electronic spectra, in the range $200-800 \mathrm{~nm}$, of the solution during the synthesis of $-\left(\mathrm{SiH}_{2}\right)$ - were obtained. Prior to solid deposition the solution gave rise to two absorption bands exhibiting differing characteristics. The shorter wavelength component remained constant in intensity and position (255 nm) during the course of the reaction. The second absorption band, observed initially at $295 \mathrm{~nm}$, shifted to Ionger waveiengths with time until attaining a limiting cut-off value at $400 \mathrm{~nm}$ prior to solid deposition. Furthermore, the intensity of the latter band increased markedly with increasing wavelength of the band maximum. A comparison of the spectra of the polysilane solution with that of r.f. a-Si is shown in figure 2. For

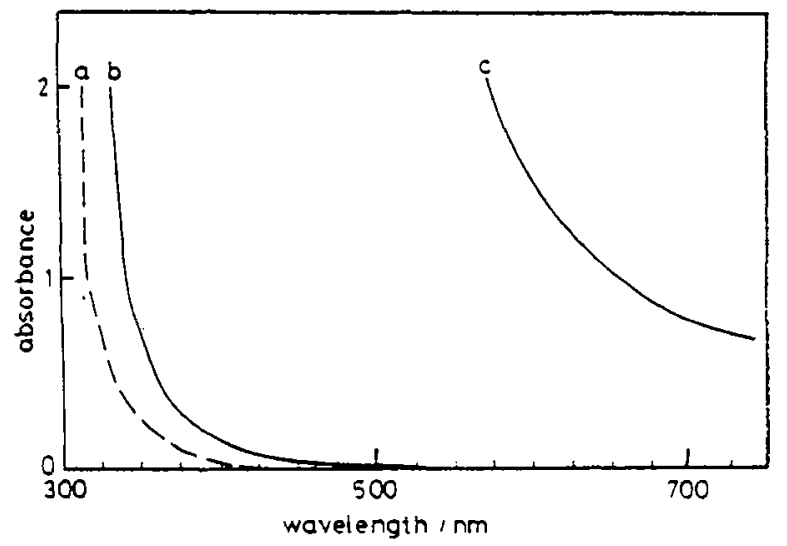

Fig. 2

Electronic spectra of partially oxidised

$-\left(\mathrm{SiH}_{2}\right) \frac{-}{\mathrm{n}}$ sample (a). $-\left(\operatorname{Sik}_{2}\right) \bar{n}$ (b) and an r.f. a-Si film (c). 
linear substituted silicon catenates, the absorption frequency, $v$, is given by the simple Hulckel molecular-orbital expression [6]

$$
h \nu=\alpha_{S i}+2 \beta_{S i S i} \cos (2 \pi / n+1)
$$

where $\alpha_{S i}, \beta_{S i S i}$ are constants and $n$ is the chain length. Enploying the former constants established for $\alpha_{3} \omega$-polysilanes the dependence of $v$ on chain length may be estimated and the results demonstrate that $n>20$. It is to be noted that branched substituted polysilanes do not exhibit frequency shifts on conjugation [6].

\subsection{Oxidative Stability}

3.3.1. Polysilane The ir transmission spectra of both materials, $-\left(\mathrm{SiH}_{2}\right)-$ and $-(\mathrm{Si}))_{-}$, were measured after exposure to moist air. Oxidation was rapld under these conditions as indicated by the pronounced changes to the ir and electronic spectra (figures 2 and 3 ). A series of distinct bands in the silicon-hydrogen stretching region were produced on oxidation arising from

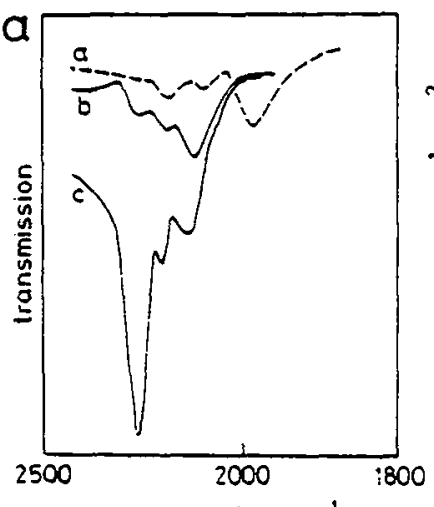

wavenumber/ $/ \mathrm{cm}^{-1}$

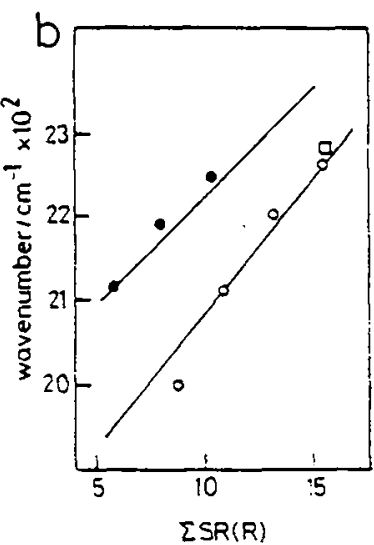

$\sum S R(R)$
Fig. 3a. Infrared

transmission spectra of partially oxidised - $(\mathrm{SiH})-$ (a) and $-\left(\mathrm{SiH}_{2}\right)-(\mathrm{b})$ Curve (c) corresponis to a sample of $-\left(\mathrm{SiH}_{2}\right)_{-}$subject to extensive oxidation.

Fig. 3b Linear relationship between the band maxima and the electronegativity sum $\sum S R(R)$. - $\equiv \mathrm{SiH} ; \mathrm{O},=\mathrm{SiH}$ derived from data of fig. $3 a . \square, \mathrm{H}$ implanted $\mathrm{SiO}_{2}$

$\equiv \mathrm{SiH}$ or $=\mathrm{SiH}$ groupings contiguously bound to one or more oxygen atoms [7]. The systematic increase in the wavenumber of the band maxima have been associated with the number and type of electronegative element bound to the silicon-hydrogen groupings [8]. The wavenumber of the peak maxima are plotted in figure 3 as a function of $[S R(R)$ where $S R$ is a measure of the electronegativity of the neighbouring atom $R$ and the sum is taken over the nearest neighbours. Each band in figure 3 can be thus associated with a particular microenvironment around the absorbing group.

Confirmation that oxidation of these materials proceeded via siliconsilicon bond fission was demonstrated by electronic spectroscopy. On exposure of the polysilane $-\left(\mathrm{SiH}_{2}\right)-$ to air the colour changes rapidly from orange/yellow to white as silicon-silicon conjugation was reduced. The effect is shown in figure 2 where the dashed line is the absorption spectrum of a polysilane solution exposed to oxygen.

3.3.2. Glow-discharge a-Si Certain r.f. films prepared at high powers (>100w) undergo oxidation when exposed to atmospheric air as shown by the development of distinctive ir bands (figure 4). The growth of bands at wavenumbers identical to those previously measured in oxidised polysilanes can be unequivocally assigned to structural groupings defined in 3.3 .1 . 


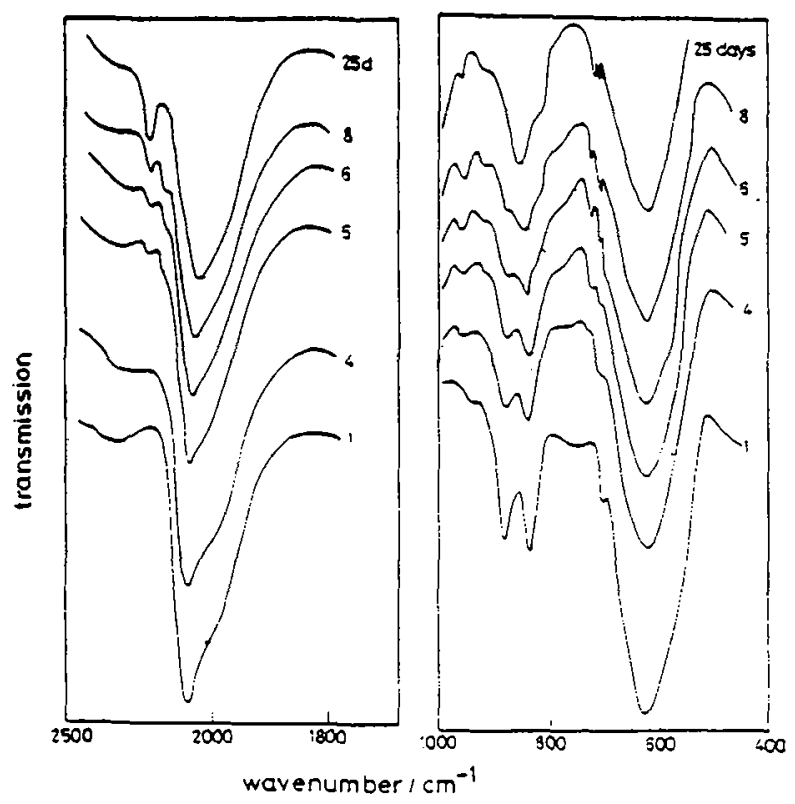

Fig. 4. Infrared transmission spectra of a high power (100W) a-si film as a function of the time of exposure to laboratory air.

4. Conclusion The chemical synthesis of $-\left(\mathrm{SiH}_{2}\right)$ - and subsequent characterisation aids the ir band assigments of hydrogenated $e^{-} S_{i}$ films. Furthermore, comparison of the ir spectra of oxidised $-\left(\mathrm{SiH}_{2}\right)_{-}$and $\mathrm{a}-\mathrm{Si}$ allow a detailed molecular explanation of the 'ageing' of glow ${ }^{2} n$ discharge a-Si films prepared at high powers.

\section{References.}

1. KNIGHTS, J.C., LUCOVSKY, G. and NEMANICH, R.J., Phil.Mag.B,37(I978)467.

2. KNIGHTS, J.C. and LUCOVSKY, G., CRC Critical Reviews in Solid State and Material Sciences, 2 (1980)211.

3. KNIGHTS, J.C., LUCOVSKY, G. and NEMANICH, R.J., J.Non-cryst.Solids, 32 (1979) 393.

4. JOHN, P., ODEH, I.M., THOMAS, M.J.K., TRICKER, M.J., RIDDOCH, F. and WILSON, J.I.B., Phil. Mag.B, 42 (1980) 671.

5. JOHN, P., ODEH, I.M., THOMAS, M.J.K., TRICKER, M.J., WILSON, J.I.B. and DHARIWAI, R.S., J.Mat.Sci., I6(1981)I305.

6. RHEINGOID, A.L. (ed) 'Homoatomic Rings, Chains and Macromolecules,' Elsevier, 1977.

7. JOHN, P., ODEH, I.M., THOMAS, M.J.K., TRICKER, M.J. and HILSON, J.I.B., Phys.Stat.Sol., in press.

8. LUCOVSKY, G., Sol.State Comm.,29(1979)571. 